ВИЩА ШКОЛА

UDC 378.4(71)+62-1

DOI https://doi.org/10.32840/1992-5786.2020.68-2.1

\author{
N. P. Vilkhovchenko \\ Ph.D. (Linguistics), Associate Professor, \\ Associate Professor of the Foreign Languages Department \\ Lviv Polytechnic National University
}

H. O. Kolesnyk

Lecturer of the Foreign Languages Department Lviv Polytechnic National University

\title{
DISCIPLINE “ENGLISH FOR SPECIFIC PURPOSES" IN TECHNICAL UNIVERSITIES: COMMUNICATIVE APPROACH
}

The paper focuses on the course "English for specific purposes" (ESP) at higher educational institutions. It plays an important role in the professional training for future specialists. The article considers a number of peculiarities of teaching ESP. Taking into account these peculiarities makes it possible to identify the most effective ways of teaching the discipline. Practicing ESP is conducted in terms of the communicative approach which is supposed to be the main condition for successful learning. The study deduces the objective of this discipline that is stipulated by the learners' needs. Therefore, it is necessary to master informative reading skills, the skills of business correspondence, writing abstracts, conducting presentations. All these skills will be important for students in their professional sphere.

The paper emphasizes the practical aspect of ESP program design. It discusses the peculiarities of developing teaching materials which are based on various communicative activities. Particular attention is given to reading, listening, writing, and speaking during the lessons. In the course of study, students have the opportunity to acquire the skills of reading different professional texts (articles, manuals, newsletters, conference abstracts etc.). In addition, they are supposed to create their own abstracts. These abstracts can be based either on the text they have read or on their coursework. Special emphasis is laid on importance of creating presentations that are connected with the material of their field of study. Such kind of work allows students to practice in creating slides for the presentation and making a report based on it. So, they can train prepared speech. Moreover, students also have an opportunity to learn how to interact with the audience. For example, they can discuss problematic issues of the report or answer some questions connected with it. These types of activity are the elements of students' unprepared speech.

The article emphasizes the value of the communicative approach and taking into account the learners' needs while teaching the discipline "English for specific purposes". It is concluded that the teacher should consider these peculiarities in her/his methodology. So, it can become a means of achieving the main goal of learning which promotes the development of students' professional competence.

Key words: ESP, technical specialties, methodology, communicative approach, needs analysis.

Formulation of the problem. "English for Specific Purposes" (ESP) has rapidly evolved through the past fifty years and has grown into one of the most important disciplines connected with English language teaching and research. Nowadays ESP teaching is gaining popularity all over the world. The Ministry of education in Ukraine stresses upon its importance in higher technical educational institutions.

So, foreign language at Ukrainian technical universities is a compulsory discipline which is normally taught starting from the first year of study. Depending on the curriculum of the institution, the length of the course normally ranges from one to four years. One of the problems which arise during the process of study is the need to combine learning lan- guage with the future profession. European integration processes influence education and awareness of the role that fluency in a foreign language plays in this process. The Department of Foreign Languages of Lviv Polytechnic National University designed the Curriculum for the discipline "English for specific purposes" (ESP) taking into account modern requirements for technical specialists. This certainly provides favorable conditions for training ESP.

Analysis of latest research and publications. The problem of effective ESP learning has been considerably investigated by numerous Ukrainian and foreign researchers (T. Dudley-Evans, M. St John, I. Imaniah, H. Shayner, N. Mukan, T. Varianko, H. Abramovych, etc.). 
The analysis of different sources proves the efficiency of communicative approach in teaching ESP, taking into account learners' needs analysis. Such researchers as J. Munby [7], P. Robinson [9] underline the importance of learners' needs analysis in developing programs for ESP courses.

While compiling the program for the discipline "English for specific purposes" for students of technical specialties, we had to consider a number of aspects characteristic to ESP. Thus, according to T. Dudley-Evans and M. St. John, ESP is characterized by various distinctive features which show how ESP differs from the course of General English [5]. Firstly, ESP is designed with the aim to meet the learners' special needs. It is usually related to specific disciplines. Secondly, it uses underlying methodology and activities of certain specialties it serves. It may sometimes use methods which differ from the "General English" ones. And finally, it is focused on lingual aspect (vocabulary, grammar, and register) and genres inherent to these special fields of study. ESP is, as a rule, intended for students with intermediate or advanced levels. Most ESP courses assume basic knowledge of the language system [5]. These major aspects became main principles that outlined the structure of the program designed for the discipline "English for specific purposes" for students of technical specialties in Lviv Polytechnic National University.

The aim of the paper is to present peculiarities of the course "English for specific purposes" for students of technical specialties that accumulates main principles of communicative approach and takes into account learner's needs.

The statement of basic material. Obviously, when teaching ESP, the teacher should choose basic textbook for each technical specialty. It is supposed to contain technical texts and must correspond to the general profile of the institute. For example, information technology students work through such texts as "Computer system", "Types of memory", "Devices for the disabled". As for the undergraduate students, they are already familiar with their future specialty and teachers face the problem of lack of textbooks in a narrow specialization. So, the teacher has to prepare the learning material for each specialty. This preparation takes place in close cooperation with the lecturers of the graduate sub-departments. ESP teacher has to select from a large number of scientific articles in a foreign language, as well as textbooks, and materials of international conferences, congresses, and symposia. Having selected the texts, teachers develop a system of exercises for each text, which are aimed at training different aspects of speech competence. The size of texts is determined by the curriculum of the discipline.

Teachers prepare methodological guidelines which include texts and exercises to work with stu- dents of definite specialties. Specialized texts are selected according to their complexity and student's competence level. At the first stage of training, these texts should not be too long. They are supposed to include the speech material students have already learned, and a small number of new lexical units. As students gain some reading experience, texts and assignments can become complicated.

At the beginning of the course, the teacher can offer the same text to all the students of the group. Later the students are able to work with different texts. They must be more or less similar according to the degree of difficulty in terms of individual capabilities. In such a way the teacher can implement the principle of individual approach to each student. The work with texts is carried out in the classroom under the guidance of the teacher, later such work becomes individual. If there are complicated and specific terms, they should be worked out with details either before or after reading the text.

In order to check reading comprehension different methods of control can be used (e. g., tests, questions on the content of the text, writing abstracts, summaries or reviews). Later on, each student is offered a separate text and given some time to process it. The student is supposed to read, understand and render the content either in writing or orally. Individual work of students with texts in the chosen subject area is considered to be necessary and useful. It will help them prepare to read various technical documents, different manuals for equipment, scientific articles, etc. in the course of their future professional activity.

University students are supposed to become familiar with two main types of individual reading, including the one aimed at understanding basic information and the one aimed at complete understanding. These types of reading differ in purpose depending on the scope of information that has to be comprehended.

The objective of the first type of reading is to teach students to be able to get information during the process of reading despite a number of lingual difficulties. They learn how to use the context and familiar word-building elements in the text. Reading technical articles with the aim of understanding basic information is normally used during the lessons.

The objective of the second type of reading is to teach students to receive detailed information from the text characterized by some lingual difficulties which are not always possible to deduce from the context. Therefore, one should use dictionaries to cope with these difficulties.

Students fulfill their individual assignments while reading technical articles aimed at complete understanding of information. Such tasks are usually given as home assignments. The texts usually contain exercises that are given either before or after 
the text. Those tasks which are given before the text include general plane questions. Their goal is to find out the main idea of the text. The assignments given after the text are dedicated to the details which help learners understand the content of the text deeper. The typical exercises include making a plan to the text or supplying the paragraphs with the headings. Among other tasks there should be the ones aimed at expressing the learner's point of view to the text they have read.

Except for reading skills, ESP teaching program includes developing listening skills, i.e. practicing perceiving and comprehending various technical texts. These texts are thoroughly prepared beforehand. The teacher should take into account important aspects of such texts. Firstly, they must not be excessively long. Secondly, they cannot be overloaded with terminology which is unfamiliar to students. Thirdly, they need to be complete in terms of content and should not include great amount of information. Pre-listening stage introduces new vocabulary that can make faithful comprehension difficult or even impossible. Postlistening stage, as a rule, includes different exercises that check students' understanding of the text they have just heard. After that they are given some questions for discussion in order to implement information they have learnt.

Another activity includes developing speaking skills. At the initial stage, students practice asking questions, requests, mini-dialogues that contain professional vocabulary. Later on, the tasks become more complicated as the students are asked to make up their own dialogues on various issues of their specialty. Role-playing appears to be an effective means of development speaking skills. However, the teacher should bear in mind that such games need thorough preparation to become a successful and efficient study tool.

Monologue speaking is another activity that holds an important position in ESP learning. Students learn how to talk about their specialty, sphere of their future activity, and various problems connected with that.

Their speaking is motivated by the specific communicative situation that activates students' cognitive activity. Problematic situations are a good incentive for a monologue speaking. It is necessary to create situations which make students think, analyze, and compare opinions and facts.

As the matter of fact, in vocational training, the use of foreign language is limited. It is normally used for compiling professional vocabulary, keywords, planning reports, writing letters, recommendations, reviews, summaries, and abstracts.

The process of learning a foreign language in modern universities presumes the use of the Internet resources. The Internet is an unlimited source of up-to-date materials in a foreign language in various professional fields. Students have an opportunity to get acquainted with the latest research, inventions, results of experiments in a particular field of knowledge. They are also able to accumulate professional and scientific terminology. Later on, they can use these materials to prepare papers for a scientific conference.

While practicing writing skills, students are supposed to prepare abstracts on the subject of their future professional activity or on the subject of their coursework, thus guaranteeing the originality of the work. After that they have to present it in the English language. Such presentations stipulate development both of general English and ESP skills.

Individual student's work on the abstract is preceded by a thorough preparatory work of the teacher, who is supposed to train students to work with original, authentic English-speaking literature of their specialty. The teacher has to provide vocabulary enrichment and mastering practical presentations skills. During ESP classes the student expands and consolidates knowledge of terminology and grammar. In order to effectively master the methodology of presentations in English on a professional topic, teachers offer students a set of exercises to develop communicative competence of oral professional communication in a foreign language. All this enables learners to practice a high-level presentation.

The presentations are usually prepared using PowerPoint program that helps listeners understand not only the general information presented in the report, but also the smallest details. The most complex specifications, classifications and features are presented on the screen in the form of diagrams, tables, figures and graphs. The use of visuals is able to simplify understanding of the speaker by low-level students.

Taking into account that the communicative aspect of learning a foreign language is dominant, one of the most important elements of presentations is an invitation to discuss the problem or the topic presented. The audience can ask the speaker questions, give comments or additional information on the topic being discussed. Such discussion is an element of unprepared, spontaneous professional communication. So, the student's attention becomes focused on the content of the speech.

To sum up, it can be emphasized that the writing the abstract and its presentation gives practical results, which are expressed in improving the communicative competence of students that is the main purpose of ESP learning in higher technical institution.

Conclusions. To sum up, communicative approach to the ESP training proves to be effective and motivating. Every activity, whether it is listening, reading, speaking or writing, should consider learners' needs, peculiarities of their specialty. It should 
be also noted that the question of ESP training is one of the most complicated issues in modern methodology. The ESP course development should be viewed as an on-going process since it is open to further methodical findings and improvements. It needs constant revision through the evaluation of its efficiency.

\section{References:}

1. Абрамович Г.В. Суть іншомовної компетентності як мети та результату професійної технічної освіти. Наукові записки. Серія «Психологопедагогічні науки». Ніжин : Вид-во НДУ ім. М. Гоголя, 2005. № 4. С. 55-58.

2. Варянко Т.В. Навчання читанню науково-технічних текстів у немовних вищих навчальних закладах. Сучасні методи викладання іноземної мови професійного спрямування у вищій школі : матеріали $\mathrm{V}$ Міжнародної науково-практичної конференції, м. Київ, 5-25 квітня 2012 р. Київ : ФЛ НТУУ «КПІ», 2012. С. 15-17.

3. Вільховченко Н.П., Шайнер Г.І. Використання методу «кейс-стаді» у навчальному процесі немовного закладу освіти України при вивченні іноземної мови. Наукові записки Національного університету «Острозька академія». Серія «Філологічна». 2016. Вип. 63. С. 216-219.
4. Шайнер Г.І., Вільховченко Н.П. Особливості дисципліни «Іноземна мова за профресійним спрямуванням» у контексті медіаосвіти. Педагогіка формування творчої особистості у вищій і загальноосвітній школах : збірник наукових праць. 2019. № 62. Т. 2. С. 31-34.

5. Dudley-Evans T., St John M.J. Developments in English for specific purposes. Cambridge : Cambridge University Press, 1998. 120 p.

6. Imaniah I., Lustyantie N. The Influence of Self Esteem Reading Habits on Student's English Essay Writing. Asian EFL Journal. 2019. № 23. P. 15-26.

7. Munby J. Communicative syllabus design: a sociolinguistic model for defining the content of purpose-specific language programmes. London : Cambridge University Press, 1978. 146 p.

8. Rahman Md., Thang S., Abd A., Mohd S. Developing an ESP Speaking Course Framework for the Foreign Postgraduates in Science and Technology at National University of Malaysia. The Asian ESP Journal. 2009. № 5. P. 18-25.

9. Robinson P. ESP today: a practitioner's guide. New York : Prentice Hall, 1991. 130 p.

\section{Вільховченко Н. П., Колесник Г. О.Дисципліна «Англійська мова за професійним спрямуванням» у технічних університетах: комунікативний підхід \\ У фоккусі роботи перебуває англійська мова за профресійним спрямуванням у закладах вищої освіти.} Курс цієї дисципліни відіграє важливу роль у професійній підготовці майбутніх фрахівців. У статті розглянуто низку особливостей, які необхідно враховувати під час викладання англійської мови за професійним спрямуванням. У роботі підкреслено важливість комунікативного підходу в навчанні. Також наголошено на тому, що завдання цієї дисципліни у професійному становленні бакалаврів технічних спеціальностей зумовлюється профресійними потребами студентів. Тому необхідним для них вважаємо оволодіння вміннями інформативного читання, навичками ділового листування, анотування, презентацій, що є важливим у майбутній профессійній діяльності.

У статті проаналізовано низку особливостей викладання іноземної мови за професійним спрямуванням студентам-бакалаврам технічних спеціальностей. Аналіз цих особливостей дав змогу визначити ефективні способи викладання дисципліни з позиції комунікативної спрямованості курсу. У роботі представлено практичну розробку навчально-методичних матеріалів стосовно різних видів діяльності. Однакову увагу під час занять приділяють роботі над читанням, аудіюванням, письмом та говорінням. У процесі навчання студенти мають змогу оволодіти навичками читання різних фрахових текстів (статей, інструкцій, тез доповідей, анотацій тощо). Крім того, студенти створюють власні анотації. Вони можуть базуватися на вже прочитаних фрахових текстах або спиратися на результати власних курсових проектів. У процесі вивчення курсу іноземної мови за профресійним спрямуванням вважаємо важливою роботу над створенням презентацій фрахового матеріалу, оскільки вона дає можливість удосконалити навички як письма, так і говоріння. Під час цієї роботи студенти практикують оформлення слайдів презентацій, а також виголошення підготовленої промови. Крім того, вони вчаться взаємодіяти з аудиторією іноземною мовою (наприклад, вести дискусії з проблемних питань доповіді, відповідати на деякі запитання). Такий вид роботи дає змогу практикувати непідготовлене мовлення.

У статті підкреслено, що комунікативний підхід з урахуванням аналізу потреб студентів $є$ засобом досягнення основної мети навчання. У своїй методиці викладач має враховувати ці принципи, що сприятиме успішному розвитку професійної компетентності студентів.

Ключові слова: англійська мова за профресійним спрямуванням, технічні спеціальності, методологія, комунікативний підхід, аналіз потреб. 